\title{
Antidiabetic Attributes of Desert and Steppic Plants: A Review
}

Authors

Affiliations
Eli Harlev ${ }^{1}$, Eviatar Nevo ${ }^{1}$, Nitsa Mirsky ${ }^{2}$, Rivka Ofir $^{3}$

${ }^{1}$ Institute of Evolution and International Graduate Center of Evolution, University of Haifa, Mount Carmel, Haifa, Israel

2 Department of Biology \& Environment, Faculty of Natural Sciences, University of Haifa, Mount Carmel, Haifa, Israel

${ }^{3}$ Dead Sea \& Arava Science Center and The Shraga Segal Department of Microbiology, Immunology \& Genetics, Ben-Gurion University of the Negev, Beer-Sheva, Israel
Key words

- desert plants

- steppic plants

- antidiabetic

oxidative stress

reactive oxygen species (ROS)

- hypoglycemic effect $\begin{array}{ll}\text { received } & \text { April 2, } 2012 \\ \text { revised } & \text { February 14, } 2013 \\ \text { accepted } & \text { February 15, 2013 }\end{array}$

Bibliography

DOI http://dx.doi.org/

10.1055/s-0032-1328331

Published online March 28,

2013

Planta Med 2013; 79: 425-436

(c) Georg Thieme Verlag KG

Stuttgart · New York ·

ISSN 0032-0943

\section{Correspondence}

\section{Eli Harlev}

Institute of Evolution and International Graduate Center of

Evolution

University of Haifa

Mount Carmel

Haifa 31905

Israel

Phone: + 97289956713

elih@research.haifa.ac.il

\section{Abstract}

$\nabla$

The rapidly increasing incidence of diabetes mellitus is becoming a serious threat to mankind's health in all parts of the world. In fact, known cases reflect only part of the problem, as many diabetics, especially with type 2 diabetes, are unaware of their disease, which initially shows no definitive symptoms. Despite the great efforts invested in diabetes research, its prevalence continues to grow, while current medications do not cover all of the symptoms and complications of the disease. The present review highlights a plethora of studies focusing on the antidiabetic

\section{Introduction}

\section{$\nabla$}

Diabetes mellitus is in a group of metabolic disorders having hyperglycemia as a common manifestation. It is a syndrome with both hereditary and environmental factors. Glycemia and diabetes are rising globally, driven both by population growth and ageing. The number of people with diabetes increased from 153 million in 1980 to 347 million in 2008 [1]. The greatest relative increase is expected to occur in Africa, followed by the Eastern Mediterranean and the Middle East [2]. The global health expenditure on diabetes has been expected to total at least USD 376 billion in 2010, rising to USD 490 billion in 3030 [3]. Diabetes is projected to become one of the world's main disablers and killers within the next 25 years [4]. Experimental diabetes in animals has provided considerable insight into the physiological and biochemical derangement of the diabetic state. Significant changes in lipid metabolism occur in diabetes as well as a profound alteration in the concentration and composition of lipids. In these cases, the lipid structural changes are clearly oxidative in nature [5]. In diabetes, increased lipid peroxidation is associated with hyperlipidemia properties of desert and semidesert (steppic) plants, many of them being used for centuries in traditional medicine by Bedouins living in the arid zones of the Middle East and also by ethnic groups in other arid and semiarid parts of the world. The review concludes in summarizing the work done on the subject and also in pointing to the yet existing gaps in diabetes research of desert and steppic plants, and suggests directions for future exploration.

Supporting information available online at http://www.thieme-connect.de/ejournals/toc/ plantamedica

[6]. Oxidative stress is, thus, produced under diabetic condition and is likely involved in the progression of pancreatic damage [7]. Despite the great strides made in the understanding and management of diabetes, the disease and its complications are increasingly unabated.

The role of oxidative stress and altered antioxidant levels in the pathogenesis of diabetic complications is well established [8]. Oxidative stress may have a common pathway linking diverse mechanisms for diabetes complications, such as vascular dysfunctions, nephropathy, neuropathy, and retinopathy. Apart from the initiation of lipid peroxidation, oxygen free radicals stimulate glycation of protein, inactivate enzymes and change the structure and function of collagen and other membranes, thereby playing a role in the longterm complications of diabetes [9]. Oxidative stress in diabetes coexists with a reduction in the antioxidant status and increase of the deleterious effects of free radicals [10]. Studies indicated that antioxidant intake may reduce the risk of developing type 2 diabetes [11]. Antioxidants were shown to reduce the risk of diabetes onset and improve glucose disposal and associated complications [12]. 
Phenolic compounds (e.g., phenolic acids, flavonoids, quinones, and tannins) are natural antioxidants abundant in many desert and steppic plants. They function as terminators of free radical chains or as chelators of redox-active metal ions capable of catalyzing lipid peroxidation [13]. A positive linear correlation was found between the antioxidant activity (the capability to scavenge oxygen reactive species) and the total phenolic content in plants $[14,15]$, suggesting that phenolic compounds contribute significantly to the antioxidant capacity of the investigated plant species. Direct correlation between the antioxidant property of medicinal plants and the latter's antidiabetic activity was found [16], and the relationship between the molecular structure of flavonoids and their radical-scavenging capability was shown [17]. Overproduction of reactive oxygen species (ROS) has been implicated in the causation of several acute diseases, such as liver cirrhosis, atherosclerosis, cancer, degenerative diseases, diabetes, and ageing. Therefore, compounds that can scavenge ROS have great potential in ameliorating or even stopping the processes leading to these diseases [18]. Antioxidants - ROS scavengers thus play important roles in protecting the human body against the damage they cause.

Ethnic medicine uses mostly plants to fight diseases. The antidiabetic effects of medicinal mushrooms and their hypoglycemic mechanism have been reviewed [19]. Sugar control is thought to be linked to the action of substances like glycosides, alkaloids, terpenoids, tannins, and flavonoids contained in medicinal plants $[4,19]$. Generally, plant-based ethnic drugs and herbal formulations are less toxic and freer from side effects than their synthetic counterparts [20].

Being exposed to harsh environmental stress conditions, desert and steppic plants have developed unique survival systems based on phytochemicals of remarkable properties. Many of them not only protect the plant against the enhanced environmental oxidative stress conditions but are thought also to be capable of diminishing, or even preventing, deleterious oxidative processes in the human body, which are involved in the development of cancer, diabetes, and neurodegenerative diseases [21].

The high potential of desert and steppic plants in treating and preventing diabetes is reflected in Bedouin ethnic medicine. Although a systematic comparison between the antidiabetic attributes of desert and semidesert plants to those of plants growing under milder conditions has not yet been documented, those of the former could still be evaluated while observing the deleterious health effects due to the changes in the lifestyle of the Israeli Negev Bedouins in the last few decades. The transition has primarily been from traditional diet (local herbs, milk from sheep, goats, and camels nourished on natural pasture) to westernized food and has resulted in a dramatic increase in diabetes morbidity and mortality among the Bedouins [22,23]. Indeed, consumption of camel milk has traditionally been regarded by the Israeli Negev Bedouins as a sure remedy against diabetes, and its ethnic use, based on experience, has recently also been scientifically validated [24-26].

This review highlights the antidiabetic effects of extracts and pure components derived from desert and steppic (semidesert) plants in ethnic medicine and in research. $\triangle$ Table 1 summarizes the plants' antidiabetic bioactivities. 0 Fig. 1 exhibits the chemical structures of antidiabetic active components included in some of them.

\section{Search Methodology}

$\nabla$

The purpose of this review article has been to provide the interested reader with a broad view, but not necessarily with complete literature coverage of the subject. Reference has been made only to plants growing mostly in arid and in semiarid zones, and used in traditional antidiabetic medicine. Others, which although being used against diabetes in ethnic medicine are basically temperate climate plants, such as Inula viscosa, for example, were not included.

Literature search has been focused on the experimental work done on the antidiabetic properties of plants traditionally used against diabetes by ethnic groups in different arid and semiarid zones of the world. The scientific search engine "SciFinder" was found to be an extremely usefull tool as it retrieves information from both MEDLINE and CAPLUS databases. In most cases, full articles were obtained and carefully gone through. In a few cases, only abstracts could be obtained. The essence of the experiments is given in the text with just a few experimental notes, such as the nature of solvent used for extraction, and the applied dosages, while ignoring experimental details.

\section{Exploring the Antidiabetic Attributes of Desert and Steppic Plants $\nabla$}

Artemisia judaica L. (Compositae) is an evergreen perennial shrub growing in the Israeli arid southern Arava and the southern Sinai desert and is commonly used in traditional Bedouin medicine. It was found that both water and alcoholic extracts of this plant significantly reduced blood glucose levels in experimentally diabetic rats, while no significant effect was detected in normal rats [27]. Phytochemical analysis of $A$. judaica revealed that it is a rich source of flavonoids, including apigenin (4',5,7-trihydroxyflavone) and cirsirmaritin ( $\bullet$ Fig. 1 ). Indeed, the major bioactive compounds of defatted alcohol and water extracts of $A$. judaica were found to be flavonoids, compounds exhibiting strong antioxidant activities $[28,29]$.

Artemisia herba-alba Asso. (also called "white wormwood"; Compositae) is a dwarf perennial shrub growing in semiarid zones and in favorable niches in hot deserts of the Middle East, but also in semiarid zones of southern Europe and Asia. The aqueous extract of $A$. herba-alba was found to produce initial hyperglycemia, followed by hypoglycemia in normal and alloxan-treated rabbits and mice [30]. This plant has been widely used in Iraqi folk medicine for the treatment of diabetes mellitus. Oral administration of an aqueous extract of its aerial parts to normoglycemic and to alloxan-diabetic rabbits produced significant hypoglycemic activity, which proved to be consistent and time dependent [31]. Hydro-alcoholic extracts of Centaurium erythraea Rafn (Gentianaceae) and $A$. herba-alba, used in the traditional treatment of diabetes in north-eastern Algeria, were tested in mice with established type 2 diabetes induced with a standardized high-fat diet [32]. At 35 weeks, groups treated with $A$. herba-alba or with $C$. erythraea when compared to the high-fat diet control showed a significant reduction in mean fasting blood glucose concentration, triglyceride, total cholesterol, and serum insulin concentrations. The plant extracts also markedly reduced insulin resistance as compared to high-fat diet controls. Although A. herba-alba has already been shown to have antihyperglycemic and antihyperlipidemic effects, this research demonstrated for the first time 
Table 1 Antidiabetic effects of desert and steppic plants.

\begin{tabular}{|c|c|c|c|c|}
\hline Plant & $\begin{array}{l}\text { Part of plant used/ } \\
\text { type of extract }\end{array}$ & Target \& antidiabetic effect & $\begin{array}{l}\text { Administration route/ } \\
\text { dosage }\end{array}$ & Reference \\
\hline Achillea santolina & $\begin{array}{l}\text { whole plant water-etha- } \\
\text { nol extract }\end{array}$ & $\begin{array}{l}\text { Reduced activities of superoxide dismutase, } \\
\text { catalase, and levels of pancreatic gluta- } \\
\text { thione in STZ diabetic male Wistar albino } \\
\text { rats; reduced blood glucose level and } \\
\text { exhibited hypoglycemic activity in STZ } \\
\text { diabetic rats. }\end{array}$ & $\begin{array}{l}\text { oral } / \mathrm{mL} / \text { rat } / \text { day (equivalent } \\
\text { to } 0.1 \mathrm{~g} \text { plant powder per } \mathrm{kg} \\
\text { b. w. per day) }\end{array}$ & $\begin{array}{l}\text { Yazdanparast et al., } 2007 \\
\text { [61] }\end{array}$ \\
\hline \multirow[t]{2}{*}{$\begin{array}{l}\text { Aloe barbadensis } \\
\text { (Aloe vera) }\end{array}$} & dried sap from leaf & $\begin{array}{l}\text { Reduced fasting serum glucose levels in } \\
\text { patients with non-insulin-dependent } \\
\text { diabetes; induced hypoglycemia in alloxan- } \\
\text { diabetic Swiss albino mice. }\end{array}$ & $\begin{array}{l}\text { oral/humans: half a tea- } \\
\text { spoonful; mice: } 0.5 \mathrm{~g} \cdot \mathrm{kg}^{-1} \\
\text { b. w. }\end{array}$ & Ghannam et al., 1986 [76] \\
\hline & $\begin{array}{l}\text { bitter principle from leaf } \\
\text { extract }\end{array}$ & $\begin{array}{l}\text { Produced hypoglycemic effect in alloxan- } \\
\text { diabetic mice. }\end{array}$ & oral $/ 5 \mathrm{mg} \cdot \mathrm{kg}^{-1} \mathrm{~b} . \mathrm{w}$. & $\begin{array}{l}\text { Channam et al., } 1986 \\
\text { [76]; Ajabnoor, } 1990 \text { [77] }\end{array}$ \\
\hline Aloe arbores-cence & $\begin{array}{l}\text { polysaccharide fraction } \\
\text { isolated from leaves }\end{array}$ & $\begin{array}{l}\text { Lowered glucose levels in normal mice, and } \\
\text { in alloxan-induced hyperglycemic mice. }\end{array}$ & oral/ad libitum & Hikino et al., 1986 [78] \\
\hline Anabasis articulata & $\begin{array}{l}\text { butyl alcohol extract of } \beta \text { - } \\
\text { sitoglucoside saponin } \\
\text { from aerial parts }\end{array}$ & $\begin{array}{l}\text { Decreased glycemia in diabetic and non-di- } \\
\text { abetic mice. }\end{array}$ & $\begin{array}{l}\text { oral } / 10 \mathrm{mg} \text { (dried butanolic } \\
\text { extract) } \mathrm{kg}^{-1} \text { b.w. }\end{array}$ & $\begin{array}{l}\text { Kambouche et al., } 2011 \\
\text { [68] }\end{array}$ \\
\hline \multirow[t]{6}{*}{ Artemisia herba-alba } & plant's aqueous extract & $\begin{array}{l}\text { Produced initial hyperglycemia, followed by } \\
\text { hypoglycemia in normoglycemic and in } \\
\text { alloxan-treated rabbits and mice. }\end{array}$ & $\begin{array}{l}\text { oral } / 0.39 \mathrm{~g} \text { (dry extract) } \\
\mathrm{kg}^{-1} \text { b.w. }\end{array}$ & Marrif et al., 1995 [30] \\
\hline & aerial parts & $\begin{array}{l}\text { Produced hypoglycemic activity to normo- } \\
\text { glycemic and to alloxan-diabetic rabbits. }\end{array}$ & $\begin{array}{l}\text { oral } / 0.39 \mathrm{~g} \text { (dry extract) } \\
\mathrm{kg}^{-1} \text { b.w. }\end{array}$ & Twaij, 1988 [31] \\
\hline & hydro-alcoholic extract & $\begin{array}{l}\text { Reduced mean fasting blood glucose, } \\
\text { serum insulin concentrations, and insulin } \\
\text { resistance in high-fat diet-induced diabetic } \\
\text { rats. }\end{array}$ & $\begin{array}{l}\text { oral } / 2 \mathrm{~g} \text { (dry extract) } \mathrm{kg}^{-1} \\
\text { b.w. }\end{array}$ & Hamza et al., 2011 [32] \\
\hline & $\begin{array}{l}\text { aqueous extract of aerial } \\
\text { parts }\end{array}$ & $\begin{array}{l}\text { Reduced blood glucose level, prevented } \\
\text { elevation of glycosylated hemoglobin level, } \\
\text { exhibited hypoliposis effect and protected } \\
\text { against body weight loss of diabetic rats and } \\
\text { rabbits. }\end{array}$ & $\begin{array}{l}\text { oral } / 0.39 \mathrm{~g} \text { (dry extract) } \\
\mathrm{kg}^{-1} \text { b.w. }\end{array}$ & $\begin{array}{l}\text { Al-Shamaony et al., } 1994 \\
\text { [33] }\end{array}$ \\
\hline & & $\begin{array}{l}\text { Lowered elevated blood sugar in patients } \\
\text { with diabetes mellitus. }\end{array}$ & & Al-Waili, 1986 [34] \\
\hline & $\begin{array}{l}\text { volatile oil from aerial } \\
\text { parts }\end{array}$ & $\begin{array}{l}\text { Decreased the high blood glucose level of } \\
\text { alloxan-diabetic rats. }\end{array}$ & $\begin{array}{l}\text { s.c.i. } / 1350-1950 \mathrm{mg} \cdot \mathrm{kg}^{-1} \\
\text { b.w. }\end{array}$ & Essway et al., 1995 [35] \\
\hline Artemisia judaica & & $\begin{array}{l}\text { Reduced blood glucose level in experimen- } \\
\text { tally diabetic rats but negligibly affected } \\
\text { normal rats. }\end{array}$ & $\begin{array}{l}\text { oral } / 0.25 \mathrm{~g} \cdot \mathrm{kg}^{-1} \text { and } \\
0.5 \mathrm{~g} \cdot \mathrm{kg}^{-1} \mathrm{~b} . \mathrm{w} \text {. for the } \\
\text { water ext. and } 0.5 \mathrm{~g} \cdot \mathrm{kg}^{-1} \\
\text { and } 1 \mathrm{~g} \cdot \mathrm{kg}^{-1} \mathrm{~b} . \mathrm{w} \text {. for the } \\
\text { alc. ext. }\end{array}$ & Nofal et al., 2009 [27] \\
\hline Atriplex halimus & $\begin{array}{l}\text { pressed juice, or water ex- } \\
\text { tract, or dialysate of the } \\
\text { green leaves }\end{array}$ & $\begin{array}{l}\text { Induced hypoglycemic effect in alloxan-dia- } \\
\text { betic albino rats. }\end{array}$ & oral & $\begin{array}{l}\text { Aharonson et al., } 1969 \\
\text { [70] }\end{array}$ \\
\hline Balanites aegyptiaca & water extract of fruits & $\begin{array}{l}\text { Decreased plasma glucose levels in diabetic } \\
\text { male rats. }\end{array}$ & oral/3.6-9 g/week/rat & Morsy et al., 2010 [59] \\
\hline \multirow[t]{2}{*}{ Calotropis procera } & dry latex from aerial parts & $\begin{array}{l}\text { Caused dose-dependent decrease in blood } \\
\text { glucose and an increase in the hepatic gly- } \\
\text { cogen content in alloxan-induced diabetic } \\
\text { rats; prevented loss of body weight in dia- } \\
\text { betic rats and brought down their daily } \\
\text { water consumption to values comparable to } \\
\text { normal rats. }\end{array}$ & oral $/ 100-400 \mathrm{mg} \cdot \mathrm{g}^{-1}$ b.w. & Roy et al., 2005 [62] \\
\hline & $\begin{array}{l}\text { water, petroleum ether, } \\
\text { and ethanol extracts of } \\
\text { leaves }\end{array}$ & $\begin{array}{l}\text { Reduced blood glucose level, total choles- } \\
\text { terol, phospholipids, low-density lipopro- } \\
\text { tein and very low-density lipoprotein and } \\
\text { increased high-density lipoprotein in STZ- } \\
\text { induced diabetic male Wister albino rats. }\end{array}$ & $\begin{array}{l}\text { oral/ } 250 \mathrm{mg} \text { (dry extract) } \\
\mathrm{kg}^{-1} \text { b.w. }\end{array}$ & $\begin{array}{l}\text { Bhaskar and Sumant, } \\
2009 \text { [63] }\end{array}$ \\
\hline Capparis spinosa & fruit & $\begin{array}{l}\text { Decreased blood glucose level in STZ- and } \\
\text { HFD-diabetic rats, normalizing it within } 2 \\
\text { weeks of daily oral administration. }\end{array}$ & $\begin{array}{l}\text { oral } / 20 \mathrm{mg} \text { (dry extract) } \\
\mathrm{kg}^{-1} \text { b.w. }\end{array}$ & $\begin{array}{l}\text { Eddouks et al., } 2004 \text { [38]; } \\
\text { Lemhadri et al., } 2007 \text { [39] }\end{array}$ \\
\hline Caralluma sinaica & $\begin{array}{l}\text { ethanol extract of aerial } \\
\text { parts }\end{array}$ & $\begin{array}{l}\text { Induced dose-dependent reduction in } \\
\text { blood glucose levels in normal male albino } \\
\text { rabbits, and brought to normal plasma } \\
\text { glucose in STZ-induced diabetic rabbits. }\end{array}$ & oral/50-200 mg/kg b.w. & $\begin{array}{l}\text { Habibuddin et al., } 2008 \\
\text { [74] } \\
\text { continued }\end{array}$ \\
\hline
\end{tabular}


Table 1 Continued

\begin{tabular}{|c|c|c|c|c|}
\hline Plant & $\begin{array}{l}\text { Part of plant used/ } \\
\text { type of extract }\end{array}$ & Target \& antidiabetic effect & $\begin{array}{l}\text { Administration route/ } \\
\text { dosage }\end{array}$ & Reference \\
\hline \multirow[t]{2}{*}{$\begin{array}{l}\text { Chiliadenus } \\
\text { iphionoides }\end{array}$} & $\begin{array}{l}\text { ethanol extract of aerial } \\
\text { parts }\end{array}$ & $\begin{array}{l}\text { Increased insulin secretion in } \beta \text { cells and } \\
\text { glucose uptake in adipocytes and skeletal } \\
\text { myotubes. Displayed hypoglycemic activity } \\
\text { in diabetic sand rats. (Psammomys obesus) }\end{array}$ & oral & Gorelick et al., 2011 [52] \\
\hline & $\begin{array}{l}\text { aqueous extract of aerial } \\
\text { parts }\end{array}$ & $\begin{array}{l}\text { Decreased blood glucose levels in diabetic } \\
\text { and in nondiabetic rats. }\end{array}$ & oral & Afifi et al., 2011 [54] \\
\hline $\begin{array}{l}\text { Larrea tridentate } \\
\text { (Creosote bush) }\end{array}$ & $\begin{array}{l}\text { nordihydro-guaiaretic } \\
\text { acid }\end{array}$ & $\begin{array}{l}\text { Decreased concentration in plasma glucose } \\
\text { of male mice without change in plasma in- } \\
\text { sulin concentration, improved oral glucose } \\
\text { tolerance and enhanced the ability of insulin } \\
\text { to lower plasma glucose concentrations. }\end{array}$ & & Luo et al., 1998 [82] \\
\hline Moringa peregrina & $\begin{array}{l}\text { aqueous and ethanol } \\
\text { extracts of aerial parts }\end{array}$ & $\begin{array}{l}\text { Induced antihyperglycemic effect on strep- } \\
\text { tozotocin-induced diabetes in rats. }\end{array}$ & $\begin{array}{l}\text { oral } / 25 \mathrm{mg} \cdot \mathrm{kg}^{-1} \text { b.w. } \\
\text { i. p. i. } / 50 \mathrm{mg} \cdot \mathrm{kg}^{-1} \text { b.w. }\end{array}$ & El-Alfy et al., 2011 [64] \\
\hline Ochradenus baccatus & & $\begin{array}{l}\text { Initiated slow hypoglycemic activity in } \\
\text { alloxanized rats. }\end{array}$ & & Shabana et al., 1990 [51] \\
\hline $\begin{array}{l}\text { Opuntia strepta- } \\
\text { cantha Lemaire }\end{array}$ & broiled nopal stems & $\begin{array}{l}\text { Induced hypoglycemic effect in patients } \\
\text { with non-insulin-dependent diabetes melli- } \\
\text { tus (NIDDM) }\end{array}$ & oral/500 g per person & $\begin{array}{l}\text { Frati-Munari et al., } 1988 \\
\text { [73] }\end{array}$ \\
\hline Peganum harmala & essential oil & $\begin{array}{l}\text { Ameliorated hyperglycemia-induced stress } \\
\text { oxidative and hepatic dysfunction in dia- } \\
\text { betic rats. }\end{array}$ & & Hamden et al., 2009 [60] \\
\hline Plantago ovata & husk hot water extract & $\begin{array}{l}\text { Suppressed rise in blood glucose after } \\
\text { sucrose loading in control and diabetic rats; } \\
\text { improved glucose tolerance in normal, type } \\
1 \text { and type } 2 \text { diabetic rats. Antihyperglyce- } \\
\text { mic activity due to increased motility of the } \\
\text { gastrointestinal tract. }\end{array}$ & oral $/ 0.5 \mathrm{~g} \cdot \mathrm{kg}^{-1}$ b. w. & Hannan et al., 2006 [67] \\
\hline \multirow[t]{3}{*}{ Retama raetam } & fruits methanol extract & $\begin{array}{l}\text { Lowered blood glucose levels in STZ-diabet- } \\
\text { ic rats. }\end{array}$ & oral $/ 250 \mathrm{mg} \cdot \mathrm{kg}^{-1}$ b. w. & $\begin{array}{l}\text { Algandaby et al., } 2010 \\
\text { [56] }\end{array}$ \\
\hline & $\begin{array}{l}\text { water extract of aerial } \\
\text { parts }\end{array}$ & $\begin{array}{l}\text { Induced hypoglycemic effect in STZ-diabet- } \\
\text { ic rats. }\end{array}$ & oral $/ 20 \mathrm{mg} \cdot \mathrm{kg}^{-1}$ b. w. & Maghrani et al., 2003 [57] \\
\hline & $\begin{array}{l}\text { water extract of aerial } \\
\text { parts }\end{array}$ & $\begin{array}{l}\text { Displayed hypoglycemic activity in both } \\
\text { normal and STZ-diabetic rats. }\end{array}$ & oral $/ 10 \mathrm{mg} \cdot \mathrm{kg}^{-1}$ b.w. & Maghrani et al., 2005 [58] \\
\hline $\begin{array}{l}\text { Terminalia chebula, } \\
\text { Terminalia helerica, } \\
\text { Emblica officinalis }\end{array}$ & $\begin{array}{l}\text { methanol extract of aerial } \\
\text { parts }\end{array}$ & $\begin{array}{l}\text { Reduced blood sugar level in normal and in } \\
\text { alloxan-treated diabetic rats. }\end{array}$ & $\begin{array}{l}\text { oral } / 100 \mathrm{mg} \cdot \mathrm{kg}^{-1} \mathrm{~b} . \mathrm{w} . \text { nor- } \\
\text { mal rats. } 120 \mathrm{mg} \cdot \mathrm{g}^{-1} \text { b.w. } \\
\text { alloxinated rats }\end{array}$ & $\begin{array}{l}\text { Sabu and Kuttan, } 2002 \\
\text { [16] }\end{array}$ \\
\hline \multirow[t]{3}{*}{ Teucrium polium } & water - ethanol extract & $\begin{array}{l}\text { Induced a decrease in glucose level and an } \\
\text { increase in blood insulin level in STZ-diabetic } \\
\text { rats. }\end{array}$ & $\begin{array}{l}\text { oral } / 0.5 \mathrm{~g} \text { (dry extract) } \mathrm{kg}^{-1} \\
\text { b.w }\end{array}$ & $\begin{array}{l}\text { Yazdanparast et al., } 2005 \\
\text { [43] }\end{array}$ \\
\hline & water extract & $\begin{array}{l}\text { Suppressed blood glucose levels; induced } \\
\text { higher GSH levels along with enhanced CAT } \\
\text { and SOD activities in pancreatic tissue; low- } \\
\text { ered serum NO, pancreatic MDA, PCO, and } \\
\text { AOPP levels. }\end{array}$ & $\begin{array}{l}\text { oral } / 0.5 \mathrm{~g} \text { (dry extract) } \mathrm{kg}^{-1} \\
\text { b. w. }\end{array}$ & Ardestani et al., 2008 [45] \\
\hline & ethanol extract & $\begin{array}{l}\text { Demonstrated insulinotropic effect on INS- } \\
1 \mathrm{E} \text { cells and a reduction of blood glucose } \\
\text { levels in both normo- and hyperglycemic } \\
\text { rats. }\end{array}$ & $\begin{array}{l}\text { intragastric/125 mg (dry } \\
\text { extract) } \mathrm{kg}^{-1} \text { b.w. }\end{array}$ & Stefkov et al., 2011 [46] \\
\hline \multirow[t]{3}{*}{ Ziziphus spina-christi } & leaf butyl alcohol extract & $\begin{array}{l}\text { Reduced serum glucose level, liver phos- } \\
\text { phorylase, and glucose-6-phosphatase (G- } \\
\text { 6-pase) activities; increased serum pyruvate } \\
\text { level and liver glycogen content and im- } \\
\text { proved glucose utilization in STZ-diabetic } \\
\text { rats. }\end{array}$ & oral $/ 100 \mathrm{mg} \cdot \mathrm{kg}^{-1}$ b.w. & $\begin{array}{l}\text { Glombitza et al., } 1994 \\
\text { [47] }\end{array}$ \\
\hline & leaf water extract & $\begin{array}{l}\text { Reduced blood glucose level, increased } \\
\text { serum insulin and C-peptide levels, reduced } \\
\text { elevated blood lactate level and elevated } \\
\text { the reduced blood pyruvate content in STZ- } \\
\text { diabetic rats. }\end{array}$ & oral $/ 200 \mathrm{mg} \cdot \mathrm{kg}^{-1}$ b. w. & Michel et al., 2011 [49] \\
\hline & $\begin{array}{l}\text { leaf butyl alcohol extract } \\
\text { or pure christinin-A }\end{array}$ & $\begin{array}{l}\text { Reduced serum glucose level and increased } \\
\text { serum insulin level in nondiabetic control } \\
\text { and in type } 2 \text {, but not in type } 1 \text { diabetic rats. }\end{array}$ & oral $/ 100 \mathrm{mg} \cdot \mathrm{kg}^{-1}$ b. w. & $\begin{array}{l}\text { Abdel-Zaher et al., } 2005 \\
\text { [50] }\end{array}$ \\
\hline
\end{tabular}

b. ..$=$ body weight; s. c. i. = subcutaneous injection; i. p. i. = intraperitoneal injection; alc. $=$ alcohol 
<smiles>O=c1cc(-c2ccc(O)cc2)oc2cc(O)cc(O)c12</smiles>

Apigenin [28.29]<smiles>COc1cc2oc(-c3ccc(O)cc3)cc(=O)c2c(O)c1OC</smiles>

Cirsirmaritin $[28,29]$<smiles>CC(C)=CC1C[C@](C)(O)C2C3CCC4C5(C)CCC(OC6OCC(O)C(OC7CC(CO)C(O)C(O)C7O)C6OC6OC(C)C(O)C(O)C6O)C(C)(C)C5CCC4(C)C3(C)COC2(C)O1</smiles>

Christinin-A [47.49.50]<smiles>CC(Cc1ccc(O)c(O)c1)C(C)Cc1ccc(O)c(O)c1</smiles>

Nordihydroguaiaretic acid $[80,81]$
Fig. 1 Several antidiabetic compounds contained in desert and steppic plants. the effect of this plant on established high-fat diet-induced diabetes.

A study assessed the efficacy and toxicity of A. herba-alba [33]. Feeding diabetic rats and rabbits with $0.39 \mathrm{~g} / \mathrm{kg}$ body weight of the aqueous extract of the aerial parts of the plant for 2-4 weeks resulted in a significant reduction in blood glucose levels, prevented elevation of glycosylated hemoglobin levels, led to hypoliposis and protected against body weight loss of the diabetic animals.

Fifteen patients with diabetes mellitus treated with A. herba-alba extract showed a considerable lowering of elevated blood sugar, while 14 out of the 15 patients had good remission of diabetic symptoms. No side effects were recorded during or after treatment with the plant extract [34].

Mice treated with the volatile oil of A. herba-alba showed significant hypoglycemia, and the high blood glucose levels of alloxantreated diabetic rats significantly decreased subsequent to injecting the oily extract [35].

The genus Capparis (Capparidaceae or Capparaceae) includes more than 250 species and has a wide distribution, particularly covering the Atlantic coasts from the Canary Islands and Morocco to the Black Sea and Armenia [36]. The species Capparis spinosa L. is a semiarid, drought tolerant perennial shrub, largely distributed throughout the Mediterranean Sea basin. In Israel, a variant, Capparis spinosa L. var. arvensis Zohary, is found throughout the 
arid part of the country, the southern Jordan Valley, Judean Desert, Negev, and Arava, growing on poor stony lands in wadies and canyons [37]. In Arab and Bedouin traditional medicine different parts of the plant have been used for treating rheumatism, women infertility, open wounds, respiratory diseases, and diabetes. The aqueous extract of the fruit of this plant was found to produce a significant decrease in blood glucose level in streptozotocin (STZ)-diabetic rats [38] and in high-fat diet (HFD) diabetic rats [39], normalizing blood glucose levels within 2 weeks of daily oral administration. Treating nondiabetic rats with the plant's extract did not result in significant changes in blood glucose levels. No changes were observed in basal plasma insulin concentrations following treatment with this plant in either normal or STZ-diabetic rats, suggesting that the underlying mechanism of its pharmacological activity is independent of insulin secretion. Teucrium polium L. (syn. Teucrium capitatum L.; Lamiaceae) is a wild-growing Mediterranean and West Irano-Turanian perennial, a plant belonging to the semiarid and arid climates of the Middle East, North Africa, south-western Asia, and southern Europe [40]. As a medicinal plant, it has been used for more than 2000 years. Traditionally, $T$. polium has been used for treating different pathological conditions, such as gastrointestinal disorders, inflammations, diabetes, and rheumatism. In Arab and Bedouin traditional medicine, $T$. polium has been primarily applied in treating abdominal pain, indigestion, diabetes, liver diseases, and hypertension [41]. During the past 40 years, different classes of compounds have been isolated from various parts of this plant, the main groups of which are terpenoids and flavonoids. These compounds possess a broad spectrum of pharmacological effects, including antioxidant, anticancer, anti-inflammatory, hypoglycemic, hepatoprotective, hypolipidemic, antibacterial, and antifungal activities [42].

The aqueous extract of the dried aerial parts of $T$. polium has traditionally been used in southern Iran. The local claimed hypoglycemic effect of this plant was validated through administering the crude extract to STZ-diabetic rats. Compared to untreated diabetic rats, the glucose level in the treated rats was decreased by $64 \%$, and an increase of almost $160 \%$ was observed in the blood insulin level. In vitro investigation using isolated rat Langerhans islets indicated that the crude aqueous extract of $T$. polium is capable of enhancing insulin secretion by almost $135 \%$ following a one dose treatment at a high glucose concentration, suggesting that a regenerative process of the islets of Langerhans in the T. polium-treated diabetic rats has occurred [43]. In another study, Gharaibeh et al. suggested that the hypoglycemic activity of aqueous extracts derived from $T$. polium is due to the enhancement of peripheral metabolism of glucose rather than an increase in insulin release [44].

Rats treated with $T$. polium extract had significantly higher glutathione (GSH) levels, along with enhanced catalase (CAT) and superoxide dismutase (SOD) activities in the pancreatic tissue. In addition to suppressed blood glucose levels, serum nitric oxide (NO), pancreatic malondialdehyde (MDA), protein carbonyl content (PCO), and advanced oxidation carbonyl products (AOPP) levels were all lower in the diabetic rats treated with the T. polium extract as compared with untreated counterparts [45].

The insulinotropic and antihyperglycemic effects of the ethanol extract of T. polium from the Republic of Macedonia, a plant traditionally used in that country to treat diabetes, were also investigated [46]. The dried extract showed a distinct in vitro insulinotropic effect on INS-1E cells at $500 \mu \mathrm{g} / \mathrm{mL}$. An oral administration of the extract to both normal and hyperglycemic rats lowered blood glucose levels of both groups by $35 \%$.

Ziziphus spina-christi (L.) Willd. (Christ's thorn jujube; Rhamnaceae) is an evergreen tree of Sudanese origin native to northern and tropical Africa, and southern and western Asia. In Israel it grows in valleys up to an elevation of $500 \mathrm{~m}$. It is also found in moist wadies in the Israeli hot Judean Desert and Arava. Z. spina-christi is a plant commonly used in Egyptian and Middle East traditional medicine for the treatment of various ailments [47, 48]. A study investigated the effect of the butyl alcohol extract of leaves of this plant and that of christinin-A ( Fig. 1), its principal saponin glycoside, in normal and STZ-induced diabetic rats [47]. In normal rats, treatment for one and four weeks produced insignificant changes in all studied parameters. However, in diabetic rats, both treatments significantly reduced serum glucose levels, liver phosphorylase, and glucose-6-phosphatase (G-6-pase) activities and significantly increased serum pyruvate levels and liver glycogen content after 4 weeks of treatment. A marked improvement was noticed in glucose utilization in diabetic rats in both cases. Serum insulin and pancreatic cyclic adenosine monophosphate (cAMP) levels showed a significant increase in diabetic rats treated with the extract, suggesting an improvement of the pancreas function.

Additional study showed that the antihyperglycemic potencies of leaf extracts of $Z$. spina-christi on STZ-induced diabetic rats depend on seasonal variation, and that leaves should preferably be collected from June to October [49]. This study showed that oral administration of $Z$. spina-christi leaf extract reduced the blood glucose level with a significant increase in serum insulin and in C-peptide levels. The extracts reduced the elevated blood lactate level and elevated the reduced blood pyruvate content of diabetic rats. In line with the amelioration of the diabetic state, $Z$. spinachristi extract, both plain and formulated, restored liver and muscle glycogen content, together with a significant decrease of hepatic glucose-6-phosphatase and enhanced the activities of glucose-6-phosphate dehydrogenase. In vitro tests marked a dose-dependent inhibitory activity of Z. spina-christi extract against $\alpha$-amylase enzyme with an $\mathrm{IC}_{50}$ at $0.3 \mathrm{mg} / \mathrm{mL}$. This work showed that $Z$. spina-christi leaf extract improves glucose utilization in diabetic rats by increasing insulin secretion, which may be due to both saponin and polyphenols contents, and controls hyperglycemia through the attenuation of meal-derived glucose absorption, attributed to the total polyphenols content.

Abdel-Zaher et al. studied the effect of butyl alcohol extract of the leaves of $Z$. spina-christi and its major saponin glycoside, christinin-A, on serum glucose and insulin levels in nondiabetic controls, type 1 and type 2 diabetic rats [50]. They found that treatment either with $100 \mathrm{mg} / \mathrm{kg}$ extract, or with christinin-A alone, reduced the serum glucose level and increased the serum insulin level of nondiabetic control and in type 2 diabetic rats, but not of type 1 diabetic rats. Similar effects were obtained with the butyl alcohol extract and with christinin-A. Pretreatment of nondiabetic control and type 2 diabetic rats, either with butyl alcohol extract or with christinin-A, enhanced the glucose lowering and insulinotropic effects of glibenclamide, a sulfonylurea antidiabetic drug used for the treatment of type 2 diabetes. It was also found that treating rats with $100 \mathrm{mg} / \mathrm{kg}$ butyl alcohol extract for 3 months produced no functional or structural disturbances in the liver and kidney and no hematological changes. These results point to the leaves of $Z$. spina-christi as a safe alternative to lower blood glucose. The safe insulinotropic and subsequent hypoglyce- 
mic effects of $Z$. spina-christi leaves could be due to a sulfonylurea-like activity.

The hypoglycemic effect of 31 plants from different Egyptian localities was tested [51]. Twenty-one plant extracts were given orally to normal rats, and fifteen were tested on fasting and alloxanized rats. The results were compared with a standard oral hypoglycemic drug [DAONIL ${ }^{\circledR}$ tablets; Daonil (INN), also known as glyburide (USAN), a second-generation sulfonylurea antidiabetic agent] used as a positive control. Eight plants exhibited persistent hypoglycemic effects, while transient hypoglycemic effects appeared in response to the administration of four other plants. Among the fifteen plant extracts tested on alloxanized diabetic rats, only four showed hypoglycemic effects more potent than those of the administered dose of DAONIL ${ }^{\circledR}$ tablets. These were Matthiola livida (Delile) DC. (Brassicaceae), Salvia aegyptiaca L. (Lamiaceae), and Arthrocnemum glaucum Ung.-Sternb. (Chenopodiaceae). S. aegyptiaca also induced the hypoglycemic effect in fasting alloxanized diabetic rats.

C. iphionoides (Boiss. \& Blanche) Brullo (syn. Varthemia iphionoides Boiss.; Compositae) is a small aromatic shrub, an herbaceous perennial hemicryptophyte distributed in the Mediterranean woodlands and shrub-steppes, deserts and extreme deserts, and is used traditionally in the treatment of diabetes mellitus. The ethanol extract of the aerial parts of $C$. iphionoides increased insulin secretion in $\beta$ cells as well as glucose uptake in adipocytes and skeletal myotubes. The extract also displayed hypoglycemic activity in diabetic sand rats (Psammomys obesus) [52].

Various extracts of the aerial parts of C. iphionoides were investigated for their radical scavenging, antioxidative, and porcine pancreas $\alpha$-amylase inhibitory activities [53]. Ethanol and water extracts showed a pronounced 1,1-diphenyl-2-picrylhydrazyl (DPPH) radical-scavenging activity, with inhibition of about $90 \%$ at a concentration of $100 \mu \mathrm{g} / \mathrm{mL}$, and $\alpha$-amylase inhibitory activity of about $70 \%$ at a concentration of $200 \mu \mathrm{g} / \mathrm{mL}$ by the 2-chloro4-nitrophenyl $\alpha$-maltotrioside (CNP-G3) degradation method. Aqueous extract of the aerial parts of $C$. iphionoides decreased blood glucose by $70 \%$ after one hour in STZ-treated rats and also lowered blood glucose in normal rats 4 hours after treatment [54].

The effect of C. iphionoides was evaluated in vitro and in vivo on enzymatic starch digestion [55]. The results confirmed that C. iphionoides could be considered a potential candidate for therapeutic modulation of impaired fasting glycemia, impaired glucose tolerance, and type 2 diabetes.

Retama raetam (Forssk.) Webb \& Berthel (Fabaceae) is a phanerophyte shrub distributed in the Mediterranean woodlands and shrublands, semi-steppe shrublands, shrub-steppes, deserts, and extreme deserts. The fruits of $R$. raetam are used in Saudi traditional medicine for the treatment of diabetes. A study evaluating the potential and mechanisms of the antidiabetic activity of $R$. raetam methanol extract in STZ-induced diabetic rats showed that the extract neither altered glucose uptake by rat isolated psoas muscle nor the activity of hepatic microsomal glucose-6phosphatase [56]. The methanol extract of $R$. raetam improved STZ-induced diabetes in rats due to stimulating pancreatic insulin release and the reduction of intestinal glucose absorption.

The effect of the aqueous extract of the leaves of $R$. raetam on blood glucose levels was investigated in fasting normal and streptozotocin-induced diabetic rats after single and repeated oral administration [57]. The aqueous extract of $R$. raetam at a dose of $20 \mathrm{mg} / \mathrm{kg}$ significantly reduced the blood glucose in normal rats
6 hours after a single oral administration and two weeks after repeated oral administration. This hypoglycemic effect was more pronounced in STZ-diabetic rats. The extract had no effect on basal plasma insulin levels, indicating an extra-pancreatic mechanism. The aqueous extract of $R$. raetam thus possesses a significant hypoglycemic effect in both normal and STZ-diabetic rats.

An additional study of the hypoglycemic activity of the aqueous extract of the aerial parts of $R$. raetam in normal and in STZ-diabetic rats following intravenous injection indicated a significant decrease in blood glucose levels in normal rats and an even more marked decrease in diabetic rats [58]. The results suggested that the hypoglycemic effect is due to an extra-pancreatic action of the extract since the basal plasma insulin concentrations remained constant. The aqueous extract perfusion of $R$. raetam caused a potent inhibition of renal glucose reabsorption. This effect indicated at least one mechanism that could explain the observed hypoglycemic activity of this plant in both normal and diabetic rats.

Balanites aegyptiaca (L.) Delile (Balanitaceae) is a multibranched, spiny shrub or tree up to $10 \mathrm{~m}$ high, native to Africa, the Arabian Peninsula, and adjacent parts of the Middle East. Within Africa it ranges from Mauritania in the west to Somalia in the east and from Egypt southwards to Zimbabwe. It is a highly drought-tolerant evergreen desert plant species, having a wide ecological distribution, but prefers open woodlands and savannahs. The fruit of a B. aegyptiaca species grown naturally at radioactive places in the Wadi El-Gemal area, Egypt, exhibited potential antidiabetic and hypolipidemic capabilities [59].

Peganum harmala L. (Syrian rue; Nitrariaceae) is a perennial shrub with fleshy spikey-looking leaves, growing up to $0.8 \mathrm{~m}$ tall. It is native to the eastern Mediterranean region and extends up to India. It can be found in diverse climates, ranging from Mediterranean to steppes and deserts. In Israel, it is distributed mainly throughout the arid and semiarid northern Negev. Treatment of diabetic rats with the essential oil of $P$. harmala ameliorated hyperglycemia-induced stress, and oxidative and hepatic dysfunction. Administration of the oil to diabetic rats initiated antidiabetic and antioxidant activities through the decrease in the plasmatic glucose level, an increase in hepatic SOD, CAT, and glutathione peroxidase activities, and a concomitant reduction in glutathione and glycogen contents compared to untreated diabetic rats [60].

Achillea santolina L. (Compositae) is a $0.3 \mathrm{~m}$ high perennial shrub, growing on loess soils in the semiarid central northern Negev in Israel. This plant is used by Bedouin traditional healers as a hypoglycemic agent. The protective effect against pancreatic damage of the hydro-ethanol extract of the plant's aerial parts was tested on STZ-treated diabetic rats [61]. Following oral administration of the extract, a significant reduction in the activities of SOD, CAT, and pancreatic GSH levels was observed in the diabetic rats, compared to control subjects. Extract of $A$. santolina reduced blood glucose level, serum NO, pancreatic MDA, PCO, and AOPP. CAT and SOD activities decreased by diabetic conditions were significantly increased in diabetic rats treated with the extract, manifesting the high hypoglycemic activity of A. santolina, an attribute probably resulting from its antioxidative potential [61].

A. santolina L., Pistacia atlantica Desf. (Anacardiaceae), Rheum ribes L. (Polygonaceae), Sarcopoterium spinosum L. Spach (Rosaceae), and T. polium L. have traditionally been used as herbal antidiabetic medicines. The in vitro and in vivo effects of water extracts of these plants were tested [55]. Compared to acarbose $\left(\mathrm{IC}_{50}=1.2 \mu \mathrm{g} / \mathrm{mL}\right)$, water extracts of $P$. atlantica, $R$. ribes, and $S$. 
spinosum exerted significant dose-dependent dual inhibition of $\alpha$-amylase and $\alpha$-glucosidase in the in vitro enzymatic starch digestion bioassay, with $\mathrm{IC}_{50}$ values of $46.98,58.9$, and $49.9 \mathrm{mg} / \mathrm{mL}$, respectively. Comparable in vivo results were obtained for starchfed rats exhibiting significant acute postprandial anti-hyperglycemic efficacies. While the extracts of $A$. santolina and T. polium lacked any favorable in vitro anti- $\alpha$-amylase and anti- $\alpha$-glucosidase effect, other modes of action can possibly explain their substantial acute anti-hyperglycemic activities in starch-treated rats. Except for $P$. atlantica extracts, none of the investigated extracts qualified for improving the glucose intolerance in fasting rats on glucose loading. $P$. atlantica, $R$. ribes, and S. spinosum are potential candidates for amelioration/management of type 2 diabetes.

Calotropis procera (Aiton) W.T. Aiton (Asclepiadaceae), also called Sodom apple, is a flowering plant growing in North Africa, tropical Africa, western Asia, south Asia, and Indochina. It is a softwooded, evergreen perennial shrub found in the hot oasis around the Dead Sea and in the Jordan Valley. It is a plant tolerant to drought and salt. The dry latex of $C$. procera, collected from its aerial parts and mixed with normal saline, was evaluated for its antioxidant and anti-hyperglycemic effects against alloxan-treated diabetic rats [62]. Daily oral administration of the dry latex produced a dose-dependent decrease in the blood glucose and an increase in the hepatic glycogen content. It also prevented the loss of body weight in diabetic rats and brought down the daily water consumption to values comparable to normal rats. The latex also increased the hepatic level of glutathione and the level of endogenous antioxidants, SOD and CAT, while bringing down the levels of thiobarbituric acid-reactive substances (TBARS) in the alloxan-induced diabetic rats. It was found that the efficacy of the dry latex as an antioxidant, and as an antidiabetic agent, was comparable to the standard antidiabetic drug, glibenclamide. Water, petroleum ether, and ethanol extracts of the leaves of $C$. procera were tested for their anti-hyperglycemic effect on STZ-induced diabetic Wister albino rats [63]. The three extracts significantly reduced the blood glucose level, total cholesterol, phospholipids, low-density (LDL), and very low-density lipoprotein (VLDL) in the treated diabetic rats and concomitantly increased the high-density lipoprotein (HDL), indicating the recovery of their lipid metabolism. This investigation established pharmacological evidence supporting the folkloric claim of the antidiabetic attributes of this plant.

Moringa peregrina (Forssk.) Fiori (Moringaceae Martinov) is a wild plant growing in the eastern desert mountains of Egypt. The aqueous and ethanol extracts of this plant were found to exert a significant anti-hyperglycemic effect on STZ-induced diabetic rats [64].

Plantago ovata Forssk. (Plantaginaceae) is a plant growing in semiarid regions of India, Iran, northern Africa, and Pakistan. It has been traditionally used for constipation, diarrhea, hemorrhoids, irritable bowel syndrome, weight loss, obesity, high cholesterol, and diabetes [65]. A patent deals with a functional powdered beverage containing the seed powder of this plant as the effective component, capable of preventing adult diseases including diabetes [66].

Administration of the husk extract of $P$. ovata significantly improved glucose tolerance in normal, type 1, and type 2 diabetic rats [67]. When orally administered with sucrose solution, the extract suppressed postprandial blood glucose and retarded the small intestinal absorption without inducing the influx of sucrose into the large intestine. It significantly reduced glucose absorption in the gut during in situ perfusion of the small intestine to nondiabetic rats. The extract did not stimulate insulin secretion in perfused rat pancreas, isolated rat islets, or clonal $\beta$ cells. Neither did it affect glucose transport in 3 T3 adipocytes. The suggested mechanism for the reduction of hyperglycemia is via the inhibition of intestinal glucose absorption and enhancement of motility.

Anabasis articulata Moq. (Amaranthaceae) is a Saharo-Arabian shrub growing in wadies and flat lands of the extreme deserts of Israel, Jordan, and Sinai. Water extracts of this plant are used in traditional medicine for the treatment of diabetes. An oral administration of butyl alcohol extract of $\beta$-sitoglucoside saponin obtained from $A$. articulata to diabetic mice decreased glycemia to $20.09 \%$ ( $\mathrm{p}<0.05$ ) six hours after administration, practically restoring to normal the blood glucose level of the diabetic mice. The results obtained indicated an antidiabetic action like a reference compound, glibenclamide [68].

A. articulata is used in Algerian traditional medicine as a remedy for diabetes [67]. The administration of the aqueous extract of the aerial part of this plant to alloxan-treated diabetic mice remarkably decreased glycemia (to nearly 30\%) 6 hours after administration. The aqueous extract contain alkaloid and saponin, but only the latter furnish the active component responsible for restoring normal blood glucose levels [69].

Atriplex halimus L. (salt bush; Amaranthaceae) is a halophyte native to Europe and Northern Africa, including the Sahara in Morocco. It grows in all parts of Israel on salty lands, in the Judean Desert, Jordan Valley, and along the Mediterranean coast. The leaves of this plant are the main feeding source for the sand rat. When these rats are fed with high-caloric diets, they develop diabetes which can be reversed by the addition of $A$. halimus leaves [70]. Alloxan-diabetic albino rats showed a significant hypoglycemic effect when fed with either pressed juice or water extract, or dialysate of the green leaves of this plant, but with no decrease in appetite [70]. A. halimus showed an insulin potentiating effect in an animal model for diabetes and obesity [71]. Another study showed the effectiveness of $A$. halimus extract against type 2 diabetic patients [72]. Indeed, tisane (herbal tea) prepared from the leaves of this plant is traditionally used by Bedouins in Israel for treating diabetes [37].

Opuntia, also known as nopales or paddle cactus, is a genus in the cactus family, Cactaceae. Currently, only prickly pears are included in this genus of about 200 species distributed throughout most of the Americas. Prickly pear species are found in abundance in Mexico, especially in the central and western regions. They are also found in the western United States, in arid regions in the Northwest, throughout the mid- and lower elevations of the Rocky Mountains, such as in the state of Colorado, where species such as Opuntia phaeacantha, Opuntia polyacantha, and others, become dominant. The hypoglycemic effect of Opuntia streptacantha Lemaire was tested, showing that the stems of this plant induce a hypoglycemic effect in patients with non-insulindependent diabetes mellitus (NIDDM) [73].

Caralluma sinaica (Decne.) A. Berger (Apocynaceae) is a plant distributed in the deserts and dry steppes of the Middle East. In Israel, it grows near the Dead Sea and in the southern Negev. Native people in the Asir region in Saudi Arabia are reported to chew this plant as a hypoglycemic herb [74]. The utility of $C$. sinaica in diabetes mellitus was examined by testing its effect on an STZ-induced diabetic model and oral glucose tolerance [74]. Administration of an ethanol/water extract of the aerial part of $C$. sinaica to normal rabbits caused a significant decrease in glucose level, while in diabetic rabbits, the plasma glucose was brought to al- 
most normal. Administration of either $C$. sinaica or glibenclamide blocked the rise of glucose caused by the STZ. The STZ-induced lowering of glycogen content of the liver and muscle was reversed by both $C$. sinaica and glibenclimide. STZ induced a significant increase in renal glycogen content, which was brought almost back to normal by the $C$. sinaica extract. Compared with the glibenclamide treatment, the blood glucose lowering effect was more pronounced for diabetic rabbits given $C$. sinaica. The above effects could explain the basis for the ethnic use of this plant in managing diabetes mellitus.

The genus Aloe comprises small to large evergreen perennials with fleshy, sword to lance-shaped leaves. This genus contains about 400 species, native to sub-Saharan Africa, the Saudi Arabian Peninsula, and to many islands of the western Indian Ocean. However, the majority are desert plants inhabiting the deserts of South Africa. The dried sap of Aloe barbadensis Mill. (syn. Aloe ve$\mathrm{ra}$; Xanthorrhoeaceae) is one of several traditional remedies used for diabetes in the Arabian Peninsula [75]. It caused a sustained lowering of blood sugar levels in patients [76], while a similar effect was obtained in alloxan-induced diabetic mice, suggesting that the hypoglycemic effect of plants of the Aloe genus may be mediated through stimulating synthesis and/or the release of insulin from Langerhans beta-cells [77].

Polysaccharide fractions from water extracts of whole leaves of Aloe arborescence Mill. reduced the glucose levels in normal mice. Two polysaccharides (glycans) were separated from the water extract of the leaves of this plant and described as arboran $A$ and arboran B. Both were found to produce marked hypoglycemic effects in normal and in alloxan-induced hyperglycemic mice [78].

\section{Surveys of Antidiabetic Desert and Semidesert Plants by Ethnic Medicine \\ $\checkmark$}

The high concentration of radical scavenging compounds in many desert and semidesert plants make them potential candidates as a source for antidiabetic drugs, which, in many cases were also proved by ethnic medicine. In the following are some examples:

Methanol extracts of Terminalia chebula Retz. (Combretaceae) and Emblica officinalis Gaertn. (Euphorbiaceae), extensively used in Indian traditional medicine and known to strongly inhibit lipid peroxidation, significantly reduced the blood sugar level in normal and alloxan-treated diabetic rats, suggesting a relationship between the antidiabetic activity and the antioxidant capability of the plants [15].

Surveying ethnomedicinal plants in the Errachidia province in south-eastern Morocco has brought to light 64 medicinal plants belonging to 33 families, of which 45 are regularly being used by the local population for treating diabetes. In this region, the most frequently used plants to treat diabetes include arid zone plants, such as P. harmala and A. herba-alba [79].

Phytotherapy is widely adopted in Morocco. A survey was undertaken in different parts of oriental Morocco, aiming at selecting the main medicinal plants used in traditional medicine to treat arterial hypertension and diabetes [80]. For diabetes, 41 plants were cited, of which the most frequently used were Trigonella foenum-graecum L. (Leguminosae), Globularia alypum L. (Globulariaceae), Artemisia herba alba Asso. (Compositae), Citrullus colocynthis (L.) Schrad. (Cucurbitaceae), and Tetraclinis articulata Benth (Cupressaceae).
An extensive ethnobotanical survey (130 informants) of the medicinal plants of Israel revealed 16 species being traditionally used for hypoglycemic treatments. The list includes desert and semi-desert plants like Achillea fragrantissima (Forssk.) Sch. Bip, A. halimus, C. spinosa, and T. polium [37].

\section{Antidiabetic Compounds Derived From Desert and Semidesert Plants \\ $\nabla$}

Larrea tridentate (Sessa \& Moc. Ex DC.) Coville (Zygophyllaceae) (creosote bush) is the most common plant in the Northern Chihuahuan Desert, particularly in the border zone of the southern USA and northern Mexico, thriving in nearly every habitat in the desert. Creosote bush is used to treat a variety of illnesses including infertility, rheumatism, arthritis, diabetes, gallbladder and kidney stones, pain and inflammation [81]. Nordihydroguaiaretic acid ( $\odot$ Fig. 1), a potent antioxidant and a well-known lipoxygenase inhibitor isolated from creosote bush, is the primary product extracted from it. It is a naturally occurring lignin, believed to reduce cell damage caused by free radicals. Under the free-radical theory of ageing, it is speculated to be responsible for the bush's long life. During the past 100 years, extensive research has demonstrated that nordihydroguaiaretic acid and its synthetic analogs are potentially useful in treating diseases related to cancers, diabetes, viral and bacterial infections, as well as inflammation [81].

The ability of masoprocol (a form of nordihydroguaiaretic acid derived from creosote bush) was evaluated in NIDDM mouse models for its ability to lower blood glucose [82]. Following oral administration of masoprocol, the plasma glucose concentration fell in male C57BL/ks-db/db or C57BL/6J-ob/ob mice. This decline was achieved without any change in plasma insulin concentration. In addition, oral glucose tolerance improved, and the ability of insulin to lower plasma glucose concentrations was accentuated in the masoprocol-treated $\mathrm{db} / \mathrm{db}$ mice. These data raise the possibility that masoprocol, or other lipoxygenase inhibitors, represent a new approach to the pharmacological treatment of type 2 diabetes.

An aqueous extract of the mesocarp of the fruits of B. aegyptiaca exhibited a prominent antidiabetic activity by oral administration in STZ-induced diabetic mice. From one of the active fractions of this extract, two new steroidal saponins were isolated, and their structures were determined as 26-O- $\beta$-D-glucopyranosyl-(25R)-furost-5-ene-3 $\beta, 22,26$-triol 3 3-O-[ $\alpha$-L-rhamnopyranosyl-( $1 \rightarrow 2)]$-[ $\beta$-D-xylopyranosyl-( $1 \rightarrow 3)]$-[ $\alpha$-L-rhamnopyranosyl$(1 \rightarrow 4)]-\beta$-D-glucopyranoside and its 22 -Me ether. In addition, 2 known saponins, 26-O- $\beta$-D-glucopyranosyl-(25R)-furost-5-ene$3 \beta, 22,26$-triol 3 -O-(2,4-di-O- $\alpha$-L-rhamnopyranosyl)- $\beta$-D-glucopyranoside and its methyl ether analog were isolated and identified. From the ethanol extract of the epicarps, 2 known flavonol glycosides, isorhamnetin-3-O-robinobioside and isorhamnetin3-O-rutinoside, were isolated and identified. Although the individual saponins did not show antidiabetic activity, combined treatment with the saponins resulted in significant activity [83]. An invention deals with a novel method for the treatment of diabetes mellitus (type 1 , impaired glucose tolerance [IGT], and type 2) by administering a therapeutically effective amount of one or both $\alpha$-glucosidase inhibitors, namely, paniculoside IV and ent16,17-dihydroxy-(-)-kauran-19-oic acid, to humans and animals [84]. Diterpenes isolated from the desert plant Pulicaria undulata (L.) C.A. Mey (Compositae) were identified as paniculoside IV and 
ent-16,17-dihydroxy-(-)-kauran-19-oic acid, both demonstrating $\alpha$-glucosidase inhibiting activity.

\section{Discussion \\ $\nabla$}

The review highlights the effects of extracts of desert and steppic plants on various parameters of diabetes including unveiling potential biochemical pathways involved. Several plant extracts influence the content of free radicals and antioxidants in treated animals, suggesting that the levels of free radicals and antioxidants are associated with the diabetic state. For example, the extract of $A$. santolina, in addition to reducing blood glucose level in diabetic rats, lead to an increase of catalase (CAT) and superoxide dismutase (SOD), whose activities used to be decreased by diabetic conditions [61]. Similarly, Calotropis procera extracts, in addition to reducing blood glucose and increasing hepatic glycogen content, also lead to an increased hepatic level of glutathione, the level of endogenous antioxidants, SOD and CAT in diabetic rats [62].

The involvement of glutathione and glutathione-related enzymes was suggested as the mechanism of action of natural antioxidant compounds [85]. Recent studies suggested that there are consistent structure-function relationships that affect bioavailability, antioxidant capacity, and the ability to induce antioxidant/detoxifying enzymes [86-88].

Flavonoids probably also function in reducing glucose levels in diabetic animals, as suggested by the case of Artemisia judaica, known to be a rich source of flavonoids and very effective in reducing blood glucose levels in experimentally diabetic rats [27]. Diabetic rats treated with extracts of $T$. polium, known to contain terpenoids and flavonoids that possess hypoglycemic effects, showed changes in various biochemical parameters related to diabetes apart from a reduced glucose level, such as serum nitric oxide (NO), pancreatic malondialdehyde (MDA), protein carbonyl content (PCO), and advanced oxidation carbonyl products (AOPP) levels [44]. The hypoglycemic activity of $C$. iphionoides Boiss is accompanied by radical-scavenging activity, suggesting that reducing radical levels contribute to better blood sugar levels [52].

The improvement of diabetes parameters by plant extracts is associated with an improvement in the lipid state, as hyperlipidemia and the oxidised forms of glycated lipids enhance insulin resistance. For example, treatment of diabetic rats with extracts of $C$. procera not only improved sugar levels in the treated diabetic animals [62,63], but also reduced total cholesterol, phospholipids, low-density (LDL) and very low-density lipoprotein (VLDL), and increased the levels of high-density lipoprotein (HDL). Extract of $A$. herba-alba produced significant hypoglycemic activity in rabbits associated with reducing triglyceride, total cholesterol, and serum insulin concentrations. In term of mechanism, it prevented the elevation of glycosylated hemoglobin levels. Preclinical studies with patients with diabetes mellitus showed that treatment with $A$. herba-alba extract caused considerable lowering of elevated blood sugar and remission of diabetic symptoms [30, 34, 35].

Several studies presented in this review pointed to the possible mode of action of the plant extract or its active moiety. For example, $Z$. spina-christi extract contains antidiabetes activity in the form of its principal saponin glycoside christinin-A. Apart from reducing serum glucose levels, liver phosphorylase, glucose-6phosphatase (G-6-pase) activities, and elevated blood lactate, it significantly increased serum pyruvate levels, liver glycogen con- tent, serum insulin, C-peptide levels, and pancreatic cyclic adenosine monophosphate (cAMP) levels in diabetic rats $[47,48]$. The hypoglycemic activity of $C$. iphionoides Boiss extract in diabetic rats can be attributed to its direct effect on insulin secretion from $\beta$ cells, glucose uptake by adipocytes, and skeletal myotubes [52]. Intravenous injection of $R$. raetam extract, apart from leading to decreased blood glucose levels in diabetic rats, also inhibited renal glucose reabsorption [57], and the administration of an ethanol/water extract of the aerial part of $C$. sinaica improved renal glycogen content in rat models [74]. One of the complications in diabetes patients is deterioration in renal function; identification of plant materials that will inhibit/delay such complications is very important.

It is important to mention that some of the plant extracts reviewed here were used traditionally by local communities in the desert and were found to be effective in the treatment of diabetes symptoms in human patients. Arab and Bedouin communities use herbal tea made of $C$. spinosa to treat patients with diabetes, and this tradition can be supported by the results of the experiment that showed that diabetic rats that consumed aqueous extract of the fruit of $C$. spinosa presented reduced glucose levels in the blood. Interestingly, herbal tea prepared from the leaves of A. halimus is used in folk medicine by Bedouins of the desert in Israel for treating diabetes [70,71]. Treatment of an animal model for diabetes and obesity with $A$. halimus extract showed a significant hypoglycemic effect with no decrease in appetite, supporting the beneficial ethnic use of this plant against diabetes in human patients.

We suggest to perform preclinical studies with patients with diabetes with several of the above-mentioned plants.

In summary, the ever increasing prevalence of the two types of diabetics in Western society could be attributed to environmental factors and to lifestyle. Thus, targeting both, meaning adopting the prevention approach, seems to be the preferred approach to cope with the problem. Current research of diabetes, as also clearly reflected in this review, focuses mainly on curing the disease.

The use of extracts of plant sources, and particularly those derived from desert and steppic plants, to treat patients with diabetes, has been shown to achieve a positive outcome. However, little efforts have as yet been directed to exploring toxicity and side effects in desert and steppic plants. Also little work was performed to investigate the action of isolated pure bioactive components derived from these plants, comparing their therapeutic activity, toxicity, and side effects to those of the crude extracts from which they were derived. Not much effort has yet been directed to clinical studies of these plants.

Owing to the accumulated traditional knowledge, desert and steppic plants used from time immemorial to prevent and cure diabetes are natural candidates for in-depth exploration. Prominent candidates mentioned in this review are A. judaica, A. herba-alba, Z. spina-christi, C. iphionoides, T. polium, and C. spinosa (particularly the evergreen var. aravensis growing on arid lands in the southern part of Israel, Jordan, and the Sinai desert). However, we also suggest other plants, not known to be of traditional use but still found to exhibit positive results in the laboratory, as candidates for in-depth exploration. Investigating the therapeutic effects of extract mixtures derived from several plants, each known to be endowed with antidiabetic properties, may become an interesting challenge too. 


\section{Supporting information}

High-resolution pictures of some Judean Desert plants used in ethnic anti-diabetes medicine and in diabetes research are available as Supporting Information.

\section{Conflict of Interest}

\section{$\nabla$}

The authors have no conflicts of interest.

\section{References}

1 Danaei G, Finucane MM, Lu Y, Singh GM, Cowan MJ, Paciorek CJ, Lin JK, Farzadfar F, Khang YH, Stevens GA, Rao M, Ali MK, Riley LM, Robinson CA, Ezzati $M$. National, regional, and global trends in fasting plasma glucose and diabetes prevalence since 1980: systematic analysis of health examination surveys and epidemiological studies with 370 countryyears and 2.7 million participants. The Lancet 2011; 378: 31-40

2 Shaw JE, Sicree RA, Zimmet PZ. Global estimates of the prevalence of diabetes for 2010 and 2030. Diabetes Res Clin Pract 2010; 87: 4-14

3 Zhang P, Zhang X, Brown J, Vistisen D, Sicree R, Shaw J, Nichols G. Global healthcare expenditure on diabetes for 2010 and 2030. Diabetes Res Clin Pract 2010; 87: 293-301

4 Neelesh M, Sanjay J, Sampa M. Antidiabetic potential of medicinal plants. Acta Pol Pharm 2010; 67: 113-118

5 Bhalodia YS, Sheth NR, Vaghasiya JD, Jivani NP. Hyperlipidemia enhanced oxidative stress and inflammatory. Int J Pharmacol 2010; 6: 25-30

6 Onody A, Csonka C, Giricz Z, Ferdinandy P. Hyperlipidemia induced by a cholesterol-rich diet leads to enhanced peroxynitrite formation in rat hearts. Cardiovasc Pharm 2003; 58: 663-670

7 Tiwari AK, Madhusudana RJ. Diabetes mellitus and multiple therapeutic approaches of phytochemicals: present status and future prospects. Curr Sci 2002; 83: 30-38

8 Maxwell SRJ, Thomason S, Sandier D, Leguen C, Baxter MA, Thrope GHG, Jones AF, Barnett AH. Antioxidant status in patients with uncomplicated insulin-dependent and non-insulin-dependent diabetes mellitus. Eur J Clin Invest 1997; 27: 484-490

9 Boynes JW. Role of oxidative stress in development of complication in diabetes. Diabetes 1991; 40: 405-412

10 Collier A, Wilson R, Bradley H, Thomson JA. Free radical activity in type 2 diabetes. Diabetic Med 1990; 7: 27-30

11 Logani MK, Davis RE. Lipid peroxidation in biologic effects and antioxidants: a review. Lipids 1979; 15: 485-493

12 Montonen J, Knekt P, Jarvinen R, Reunanen A. Dietary antioxidant intake and risk of type 2 diabetes. Diabetes Care 2004; 27: 362-366

13 Schroeter HC, Boyd JPE, Spencer RJ, Williams EC, Rice-Evans C. MAPK signaling in neurodegeneration: influences of flavonoids and of nitric oXide. Neurobiol Aging 2002; 23: 861-880

14 Al-Mustafa AH, Al-Thunibat OY. Antioxidant activity of some Jordanian medicinal plants used traditionally for treatment of diabetes. Pakistan J Biol Sci 2008; 11: 351-358

15 Tawaha K, Alali FQ Gharaibeh M, Mohammad M, El-Elimat T. Antioxidant activity and total phenolic content of selected Jordanian plant species. Food Chem 2007; 104: 1372-1378

16 Sabu MC, Kuttan R. Anti-diabetic activity of medicinal plants and its relationship with their antioxidant property. J Ethnopharmacol 2002; 81: $155-160$

17 Rice-Evans CA, Miller NJ, Paganga G. Structure-antioxidant activity relationships of flavonoids and phenolic acids. Free Radic Biol Med 1996; 20: 933-956

18 Valco MM, Mazur M, Rhodes CJ, Telser J. Role of oxygen radicals in DNA damage and cancer incidence. Mol Cell Biochem 2004; 266: 37-56

19 Lo HC, Wasser PS. Mushrooms for glycemic control in diabetes mellitus: history, current status, future perspectives and unsolved problems (review). Int J Med Mushrooms 2011; 13: 401-426

20 Sahu P, Sharma A, Chatterjee T. Natural products with potent hypoglycemic activity. Res J Pharm Technol 2010; 3: 650-656

21 Mukherjee S, Gogoi JB. Free radicals in diseases and potential role of phytoconstituents. Curr Chem Biol 2011; 5: 197-212

22 Fraser D, Abu-Saad K, Abu-Shareb $H$. The relative importance of traditional and "modern" foods for Israeli Negev Bedouins. A population in transition. Nutr Metab Cardiovasc Dis 2001; 11: 66-69
23 Abou-Rbiah Y, Weitzman S. Diabetes among Bedouins in the Negev: the transition from a rare to a highly prevalent condition. Isr Med Assoc J 2002; 4: 687-689

24 Agrawal RP, Awami SC, Beniwal R, Kochar DK, Shani MS, Tuteja FC, Ghorui SK. Effect of camel milk on glycemic control, lipid profile and diabetes quality of life in type 1 diabetes: A randomised prospective controlled cross over study. Indian J Animal Sci 2003; 73: 1105-1110

25 Agrawal RP, Kochar KD, Sahani MS, Tuteja FC, Ghorui SK. Hypoglycemic activity of camel milk in streptozotocin induced diabetic rats. Int J Diabetes Dev Ctries 2004; 24: 47-49

26 Agrawal RP, Beniwal R, Sharma S, Kochar DK, Tuteja FC, Ghorui SK, Sahani MS. Effect of raw camel milk in type 1 diabetic patients: 1 year randomised study. J Camel Pract Res 2005; 12: 27-35

27 Nofal SM, Mahmoud SS, Ramadan A, Soliman GA, Fawszy R. Anti-diabetic effect of Artemisia judaica extracts. Res J Medicine Med Sci 2009; 4: 42-48

28 Liu CZ, Murch SJ, El-Demerdash M, Saxena PK. Artemisia judaica L.: micropropagation and antioxidant activity. J Biotechnol 2004; 110: 6371

29 El-Massry KF, El-Ghorab AH, Farouk A. Antioxidant activity and volatile components of Egyptian Artemisia judaica L. Food Chem 2002; 79: 331-336

30 Marrif HI, Ali BH, Hassan KM. Some pharmacological studies on Artemisia herba-alba (Asso.) in rabbits and mice. J Ethnopharmacol 1995; 49: 51-55

31 Twaij HA, Al-Badr AA. Hypoglycemic activity of Artemisia herba-alba. J Ethnopharmacol 1988; 24: 123-126

32 Hamza N, Berke B, Cheze C, Le Garrec R, Lassalle R, Agli AN, Robinson P, Gin $H$, Moore N. Treatment of high fat diet induced type 2 diabetes in C57BL/6J mice by two medicinal plants used in traditional treatment of diabetes in the east of Algeria. J Ethnopharmacol 2011; 133: 931933

33 Al-Shamaony L, Al-Khazraji SM, Twaij HA. Hypoglycaemic effect of Artemisia herba alba. II. Effect of a valuable extract on some blood parameters in diabetic animals. J Ethnopharmacol 1994; 43: 167-171

34 Al-Waili MSD. Treatment of diabetes mellitus by Artemisia herba-alba extract: preliminary study. Clin Exp Pharmacol Phys 1986; 13: 569573

35 Essway GS, Sobbhy HM, El-Banna HA. The hypoglycemic effect of volatile oil of some Egyptian plants. Vet Med J 1995; 43: 167-172

36 Saadaoui Z, Guetat A, Tlili N, El Gazzah M, Khaldi A. Subspecific variability of Tunisian wild populations of Capparis spinosa L. J Med Plants Res 2011; 5: 4339-4348

37 Yaniv Z, Dafni A, Friedman J, Palevitch D. Plants used for the treatment of diabetes in Israel. J Ethnopharmacol 1987; 19: 145-151

38 Eddouks M, Lemhadri A, Michel JB. Caraway and caper: potential antihyperglycaemic plants in diabetic rats. J Ethnopharmacol 2004; 94 : 143-148

39 Lemhadri A, Eddouks M, Sulpice T, Burcelin R. Anti-hypergliceamic and anti-obesity effects of Capparis spinosa and Chamaemelum nobile aqueous extracts in HFD mice. Am J Pharmacol Toxicol 2007; 2: 106-110

40 Afifi FU, Abu-Irmaileh BE, Al-Noubani RA. Comparative analysis of the essential oils of Teucrium polium L. grown in different arid \& semi arid habitats in Jordan. Jordan J Pharm Sci 2009; 2: 42-52

41 Palevitch D, Yaniv Z. Medicinal plants of the Holy Land. Tel Aviv, Israel: Modan; 2000

42 Bahramikia S, Yazdanparast R. Phytochemistry and medicinal properties of Teucrium polium L. (Lamiaceae). Phytother Res, advance online publication 17 Feb 2012; DOI: 10.1002/ptr.4617

43 Yazdanparast R, Esmaeili MA, Halen JA. Teucrium polium extract effects pancreatic function of Streptozotocin diabetic rats: A histopathological examination. Iranian Biomed J 2005; 9: 81-85

44 Gharaibeh MN, Elayan HH, Salhab AS. Hypoglycemic effects of Teucrium polium. J Ethnopharmacol 1988; 24; 93-99

45 Ardestani A, Yazdanparast R, Jamshidi S. Therapeutic effects of Teucrium polium extract on oxidative stress in pancreas of streptozotocin-Induced diabetic rats. J Med Food 2008; 11: 525-532

46 Stefkov G, Kulevanova S, Miova B, Dinevska-Kjovkarovska S, Molgaard P. Jager AK, Josefsen K. Effects of Teucrium polium spp. capitatum flavonoids on the lipid and carbohydrate metabolism in rats. Pharm Biol 2011; 49: 885-892

47 Glombitza KW, Mahran GH, Mirhom KG, Michel YW, Motawi TK. Hypoglycemic and antihyperglycemic effects of Zizyphus spina-christi in rats. Planta Med 1994; 60: 244-247 
48 Adzu B, Amos S, Wambebe C, Gamaniel K. Antinociceptive activity of Zizyphus spina-christi root bark extract. Fitoterapia 2001; 4: 344-350

49 Michel CG, Nesseem DI, Ismail MF. Anti-diabetic activity and stability study of the formulated leaf extract of Zizyphus spina-christi (L.) Willd with the influence of seasonal variation. J Ethnopharmacol 2011; 133: 53-62

50 Abdel-Zaher AO, Salim SY, Assaf MH, Abdel-Hady RH. Antidiabetic activity and toxicity of Zizyphus spina-christi leaves. J Ethnopharmacol 2005; 101: 129-138

51 Shabana MM, Mirhom YW, Genenah AA, Aboutabl EA, Amer HA. Study into wild Egyptian plants of potential medicinal activity. Ninth communication: hypoglycaemic activity of some selected plants in normal fasting and alloxanised rats. Arch Exp Veterinarmed 1990; 44: 389394

52 Gorelick J, Kitron A, Pen S, Rozenzweig T, Madar Z. Anti-diabetic activity of Chiliadenus iphionoides. J Ethnopharmacol 2011; 137: 1245-1249

53 Al-Dabbas MM, Kitahara K, Suganuma T, Hashimoto F, Tadera K. Antioxidant and $\alpha$-amylase inhibitory compounds from aerial parts of Varthemia iphionoides Boiss. Biosci Biotechnol Biochem 2006; 70: 2178-2184

54 Afifi FU, Saket M, Jaghabir M, Al-Eisawi D. Effect of Varthemia iphionoides on blood glucose level of normal rats and rats with streptozonic-induced diabetes mellitus. Curr Ther Res 1997; 58: 888-892

55 Kasabri V, Afifi FU, Hamdan I. In vitro and in vivo acute antihyperglycemic effects of five selected indigenous plants from Jordan used in traditional medicine. J Ethnopharmacol 2011; 133: 888-896

56 Algandaby MM, Alghamdi HA, Ashour OM, Abdel-Naim AB, Ghareib SA, Abdel-Sattar EA, Hajar S. Mechanisms of the antihyperglycemic activity of Retama raetam in streptozotocin-induced diabetic rats. Food Chem Toxicol 2010; 48: 2448-2453

57 Maghrani M, Lemhadri A, Jouad H, Michel JB, Eddouks M. Effect of the desert plant Retama raetam on glycaemia in normal and streptozotocin-induced diabetic rats. J Ethnopharmacol 2003; 87: 21-25

58 Maghrani M, Michel JB, Eddouks M. Hypoglycaemic activity of Retama raetam in rats. Phytother Res 2005; 19: 125-128

59 Morsy AMA, Ahmad IA, Kamel AM. Some biomedical applications of Balanites aegyptiaca grown naturally in radioactive area, Southeastern Desert, Egypt. J Hazard Mater 2010; 178: 725-728

60 Hamden K, Carreau S, Jamoussi K, Ayadi F, Garmazi F, Elfeki A. Dietary Nigella sativa and Peganum harmala oils reverses hyperglycaemia, hepatotoxicity, and metabolism in rats. Food Sci Biotechnol 2009; 18: 739-744

61 Yazdanparast R, Ardestani A, Jamshidi S. Experimental diabetes treated with Achillea santolina: effect on pancreatic oxidative parameters. J Ethnopharmacol 2007; 112: 13-18

62 Roy S, Sehgal R, Padhy BM, Kumar VL. Antioxidant and protective effect of latex of Calotropis procera against alloxan-induced diabetes in rats. J Ethnopharmacol 2005; 102: 470-473

63 Bhaskar VH, Sumant SA. Evaluation of antihperglycemic activity of extracts of Calotropis procera (Ait.) R.Br on streptozotocin induced diabetic rats. Global J Pharmacol 2009; 3: 95-98

64 El-Alfy TS, Ezzat SM, Hegazy AK, Amer AMM, Kamel GM. Isolation of biologically active constituents from Moringa peregrina (Forssk.) growing in Egypt. Pharmacogn Mag 2011; 7: 109-115

65 Mehta KG, Modi R, Gupta R. "Psyllium”. Indian J Agron 1976; 21: 509510

66 Watanabe S, Aoki T. Functional powdered beverage containing fiber powder of Plantago ovata effective component. JP Patent 04036173A19920206; 1992

67 Hannan JMA, Ali L, Khaleque J, Akhter M, Flatt PR, Abdel-Wahab YHA. Aqueous extracts of husks of Plantago ovata reduce hyperglycaemia in type 1 and type 2 diabetes by inhibition of intestinal glucose absorption. Br J Nutr 2006; 96: 131-137

68 Kambouche N, Merah B, Derdour A, Bellahouel S, Younos C, Soulimani $R$. Antihyperglycemic activity of $\beta$-sitoglucoside sterol isolated from the plant of Anabasis articulata (Forssk) Moq. Phytotherapie 2011; 9: 2-6
69 Kambouche N, Merah B, Derdour A, Bellahouel S, Benziane MM, Younos C, Firkioui M, Bedouhene S, Soulimani R. Study of anti-diabetic effect of saponins extracted from Anabasis articulata (Forssk) Moq, a plant traditionally used in Algeria. Phytotherapie 2009; 7: 197-201

70 Aharonson Z, Shani J, Sulman FG. Hypoglycaemic effect of the salt bush (Atriplex halimus), a feeding source of the sand rat (Psammomys obesus). Diabetologia 1969; 5: 379-383

71 Shani J, Ahronson Z, Sulman FG, Mertz W, Frenkel G, Kraicer PF. Insulinpotentiating effect of salt bush (Atriplex halimus L.) ashes. Isr J Med Sci 1972; 8: 757-758

72 Stern E. Successful use of Atriplex halimus in the treatment of type 2 diabetic patients: a preliminary study. Tel Aviv: Zamenhoff Medical Center; 1989 (unpublished results)

73 Frati-Munari AC, Gordillo BE, Altamirano P, Ariza CR. Hypoglycemic effect of Opuntia streptacantha Lemaire in NIDDM. Diabetes Care 1988; 11: 63-66

74 Habibuddin M, Daghriri HA, Humaira T, Al-Qahtani MS, Hefzi A. Antidiabetic effect of alcoholic extract of Caralluma sinaica L. on streptozotocin-induced diabetic rabbits. J Ethnopharmacol 2008; 117: 215-220

75 Grindlay $D$, Reynolds $T$. The Aloe vera phenomenon: a review of the properties and modern uses of the leaf parenchyma gel. J Ethnopharmacol 1986; 16: 117-151

76 Ghannam N, Kingston M, Al-Meshaal IA, Tariq M, Parman NS, Woodhouse $N$. The antidiabetic activity of aloes: preliminary clinical and experimental observations. Hormone Res 1986; 24: 288-294

77 Ajabnoor MA. Effect of aloes on blood glucose levels in normal and alloxan diabetic mice. J Ethnopharmacol 1990; 28: 215-220

78 Hikino H, Takahashi M, Murakami M, Konno C, Mirin Y, Karikura M, Hayashi T. Isolation and hypoglycemic activity of arborans A and B, glycans of Aloe arborescens var. natalensis leaves. Int J Crude Drug Res 1986; 24: 183-186

79 Tahraoui A, El-Hilaly J, Israili ZH, Lyoussi B. Ethnopharmacological survey of plants used in the traditional treatment of hypertension and diabetes in south-eastern Morocco (Errachidia province). J Ethnopharmacol 2007; 110: 105-117

80 Ziyyat A, Legssyer A, Mekhfi H, Dassouli A, Serhrouchni M, Benjelloun W. Phytotherapy of hypertension and diabetes in oriental Morocco. J Ethnopharmacol 1997; 58: 45-54

81 Arteaga S, Andrade-Cetto A, Cardenas R. Larrea tridentata (Creosote bush), an abundant plant of Mexican and US-American deserts and its metabolite nordihydroguaiaretic acid. J Ethnopharmacol 2005; 98: 231-239

82 Luo J, Chuang T, Cheung J, Quan J, Tsai J, Sullivan C, Hector RF, Reed MJ, Meszaros K, King SR, Carlson TJ, Reaven GM. Masoprocol (nordihydroguaiaretic acid): a new antihyperglycemic agent isolated from the creosote bush (Larrea tridentata). Eur J Pharmacol 1998; 346: 77-79

83 Kamel MS, Ohtani K, Kurokawa T, Assaf MH, El-Shanawany MA, Ali AA, Kasai R, Ishibashi S, Tanaka O. Studies on Balanites aegyptiaca fruits: an antidiabetic Egyptian folk medicine. Chem Pharmacol Bull 1991; 39: 1229-1233

84 Ahmad VU, Rasool N, Choudhary MI, Khan SN. New treatment of diabetes mellitus. US Patent US 20070287674A120071213; 2007

85 Masella R, Di-Benedeto R, Vari R, Filesi C, Giovannini C. Novel mechanisms of natural antioxidant compounds in biological systems: involvement of glutathione and glutathione-related enzymes. J Nutr Biochem 2005; 16: 577-586

86 Van Zanden JJ, Geraets L, Worteboer HM, Van Bladeren PJ, Rietjens IMCM, Cnubben NHP. Structural requirements for the flavonoid-mediated modulation of glutathione S-transferase and GS-X pump activity in MCF7 breast cancer cells. Biochem Pharmacol 2004; 67: 1607-1617

87 Depeint F, Gee JM, Williamson G, Johnson IT. Evidence for consistent patterns between flavonoid structures and cellular activities. Proc Nutr Soc 2002; 61: 97-103

88 Fukao T, Hosono T, Misawa S, Seki T, Ariga T. The effects of allyl sulfides on the induction of phase II detoxification enzymes and liver injury by carbon tetrachloride. Food Chem Toxicol 2004; 42: 743-749 